\title{
ANALISIS CITRA DIGITAL UNTUK SAMPEL BATUAN MENGGUNAKAN MICRO-CT SCANNER SKYSCAN 1173
}

\author{
Aceng Kurnia Rochmatulloh ${ }^{1, a)}$, Ulpa Zein Fawziah ${ }^{1)}$, \\ Rizki Fahmi Sumaryono ${ }^{1)}$, Selly Feranie ${ }^{1)}$, Fourier Dzar Eljabbar Latief ${ }^{2)}$ \\ ${ }^{1}$ Departemen Pendidikan Fisika FPMIPA UPI, Jl. Dr. Setiabudi No 299, Bandung 40154. \\ ${ }^{2}$ Fisika Bumi dan Sistem Kompleks FMIPA ITB, Jl. Ganesha No. 10, Bandung 40132. \\ Email: ${ }^{a}$ kurniaaceng2012@gmail.com
}

\begin{abstract}
Abstrak
Analisis citra digital telah dilakukan pada sampel batuan hasil pemindaian menggunakan Micro-CT Scanner Bruker Skyscan 1173. Analisis dilakukan secara kualitatif dan kuantitatif untuk mengetahui karakteristik dari citra sampel batuan. Sampel digital batuan yang dihasilkan dari proses pemindaian tersebut berukuran $380 \times 380 \times 380$ piksel. Analisis kualitatif dilakukan dengan menggunakan perangkat lunak CTAn (2D) dan CTVox (3D). Analisis kuantitatif dilakukan dengan perhitungan ukuran pori, porositas terbuka, porositas tertutup, porositas total serta dimensi fraktal menggunakan perangkat lunak CTAn. Analisis konsensus penggunaan sumbu kartesian dari data digital dalam perangkat lunak yang digunakan (CTAn, CTVox, DataViewer, ImageJ dan Matlab) dilakukan dengan menelaah citra 2D irisan trans-axial (bidang $X Y$ ), sagittal (bidang $Z Y$ ), dan coronal (bidang $X Z$ ). Hasil parameter-parameter batuan yang dianalisis pada sampel batuan menunjukan bahwa batuan termasuk ke dalam golongan fanerik/fanerokristalin halus, memiliki porositas yang tergolong istimewa, pori-pori pada batuan terkoneksi dengan baik, serta aliran fluida pada batuan cukup kompleks.. Hasil perbandingan posisi sampel batuan yang diperoleh dari berbagai perangkat lunak menunjukkan kesamaan citra irisan pada perangkat lunak CTAn, CTVox, dan DataViewer, namun berbeda dengan hasil citra irisan pada ImageJ dan Matlab sehingga perlu perubahan sumbu kordinat jika dalam pemrosesan lanjut menggunakan kedua perangkat tersebut.
\end{abstract}

Kata-kata kunci: analisis citra digital, porositas, dimensi fraktal, medium berpori.

\begin{abstract}
Digital image analysis has been done on rock samples of scanning results using Bruker Skyscan 1173 Micro-CT Scanner. The analysis is done qualitatively and quantitatively to know the characteristics of the sample image of the rock. The digital samples of rock produced from the scanning process are $380 \times$ $380 \times 380$ pixels in size. Qualitative analysis is done by using CTAn (2D) and CTVox (3D) software. Quantitative analysis is done by calculating pore size, open porosity, closed porosity, total porosity and fractal dimension using CTAn software. The consensus analysis of the use of Cartesian axes of digital data in the software used (CTAn, CTVox, DataViewer, ImageJ and Matlab) is done by examining 2D trans-axial imagery $(X Y)$, sagittal (field $Z Y$ ), and coronal $(X Z)$. The results of the rock parameters analyzed in the rock samples indicate that the rocks belong to the type of faneric/fine fanerokristalin, have a porosity that is special, the pores in the rock are well connected, and the fluid flow in the rock is quite complex. Rock samples obtained from various software show similarities of image on CTAn, CTVox, and DataViewer software, but unlike the image of ImageJ and Matlab so it is necessary to change the coordinate axis if in advanced processing using both devices.
\end{abstract}

Keywords: digital image analysis, porosity, fractal dimension, porous media. 


\section{PENDAHULUAN}

Studi mengenai analisis citra digital telah dikembangkan oleh para peneliti, terutama analisis mengenai struktur pori serta porositas pada sampel batuan. Teknik pencitraan, seperti computed tomography (CT), microcomputed tomography (microCT), dan focused ion beam-scanning electron microscopy (FIB-SEM) dapat membantu kita untuk mendapatkan citra 3D dengan resolusi tinggi. Teknik computed tomography (CT) merupakan teknik eksposi radiografi beberapa arah yang digunakan untuk mengatasi tumpang-tindih citra (overlaping) seperti pada metode citra sinar- $\mathrm{x}$ konvensional yang hanya merupakan proyeksi satu arah, Sutapa dkk [1]. Sebuah citra batuan digital 3D beresolusi tinggi, dapat menangkap semua selukbeluk dan detail pori dari batuan sampel sehingga dapat mengetahui parameter fisis seperti porositas, ukuran pori, permeabilitas dan dimensi fraktal. Dapat pula kemudian disimulasikan proses fisik dan mekanik pada batuan, seperti aliran fluida dan deformasi elastis menggunakan hukum dasar fisika dan metode numerik, tanpa harus melakukan uji coba laboratorium yang sulit dilakukan.

Beberapa studi mengenai analisis citra digital telah dikembangkan oleh para peneliti, di antaranya Roger [2] telah mengembangkan analisis citra digital batuan untuk deskripsi kuantitatif dengan menggunakan contoh dari tiga reservoir karbonat yang berbeda. Serta Karimpouli dkk [3] telah melakukan penelitian tentang sebuah strategi alternatif dalam bidang fisika batuan digital yaitu rekonstruksi kondisional dan telah mengembangkan proses analisis citra yang dimodifikasi dengan menggunakan metode statistik tingkat tinggi. Aplikasi dari pengembangan kajian fisika mengenai struktur pori ini salah satunya adalah untuk menganalisis distribusi pori serta rekahan pada suatu batuan. Analisis distribusi pori serta rekahan pada suatu batuan telah diteliti oleh Latief dkk [4] tentang teknik isolasi digital untuk rekonstruksi dan visualisasi dari rekahan pada batuan reservoir panas bumi.

Salah satu parameter fisis yang digunakan untuk menganalisis struktur pori pada medium berpori adalah porositas. Studi mengenai analisis citra digital yang telah dikembangkan oleh para peneliti di antaranya oleh Furmann dkk [5] telah melakukan penelitian tentang porositas dan struktur pori pada batuan lempung di daerah Alberta, Kanada. Porositas sering digunakan untuk menganalisis besar penyimpanan minyak bumi dan gas pada reservoir konvensional.

Tujuan dari penelitian ini adalah untuk melakukan analisis secara kualitatif dan kuantitatif serta mengetahui karakteristik dari citra batuan reservoir geothermal. Analisis kualitatif dapat dilakukan melalui pemeriksaan visual citra sampel dengan menggunakan perangkat lunak DataViewer (2D) dan CTVox (3D), sedangkan analisis kuantitatif melibatkan perhitungan ukuran pori, porositas terbuka, porositas tertutup, porositas total serta dimensi fraktal melalui pendekatan komputasi menggunakan perangkat lunak CTAn. Tujuan lainnya adalah untuk melakukan analisis konsensus pengolahan citra pada berbagai perangkat lunak yang digunakan (CTAn, CTVox, DataViewer, ImageJ dan Matlab). Analisis konsensus dilakukan dengan menelaah citra 2D irisan trans-axial (bidang $X Y$ ), sagittal (bidang $Z Y$ ), dan coronal (bidang $X Z$ ).

\section{METODE}

Sampel batuan dalam penelitian ini diperoleh dari daerah Kamojang, Jawa Barat kurang lebih 17 $\mathrm{km}$ Baratlaut dari Kabupaten Garut (lihat pada GAMBAR 1 a). Sampel batuan yang digunakan berbentuk kubus dengan ukuran $35 \mathrm{~mm} \times 35 \mathrm{~mm} \times 35 \mathrm{~mm}$. Sampel digital batuan dipindai menggunakan perangkat micro-CT Scanner Bruker Skyscan 1173 serta melalui serangkaian prosedur pengolahan citra sehingga dihasilkan sampel 3D berukuran $380 \times 380 \times 380$ piksel (dapat dilihat pada GAMBAR 1 b). Adapun prosedur pengolahan citra yang dilakukan guna menghasilkan citra digital batuan adalah sebagai berikut. Pertama pemindaian dilakukan pada sampel batuan menggunakan perangkat microCT Scanner Bruker Skyscan 1173 dan menghasilkan sejumlah citra hasil atenuasi 2D atau disebut dengan citra proyeksi (projection image) (pada GAMBAR 2 a).

Sejumlah citra citra proyeksi kemudian direkonstruksi menggunakan perangkat lunak NRecon sehingga menghasilkan sejumlah citra 2D yang disebut reconstructed image (citra rekonstruksi) (pada GAMBAR 2 b). Selanjutnya citra reconstructed image dapat diproses menggunakan beberapa 
perangkat lunak tergantung dari hasil apa yang diinginkan oleh penulis. Untuk pengolahan analisis kualitatif citra 2D serta analisis kuantitatif citra 3D penulis menggunakan perangkat lunak CTAn. Dari hasil pengolahan citra untuk analisis kualitatif 2D diperoleh sebuah citra greyscale 2D di mana skala abu bergantung pada tingkat atenuasi pada sampel batuan dan merupakan citra trans-axial (bidang $x y$ ) (dapat dilihat pada GAMBAR 2 c), dari citra GAMBAR 2 dapat diubah menjadi citra distribusi parameter batuan di mana nilainya diwakili oleh warna pada batuan (lihat pada GAMBAR 2 d). Dari hasil pengolahan data untuk analisis kuantitatif citra 3D diperoleh TABEL yang berisi parameter-parameter fisis batuan beserta nilainya.

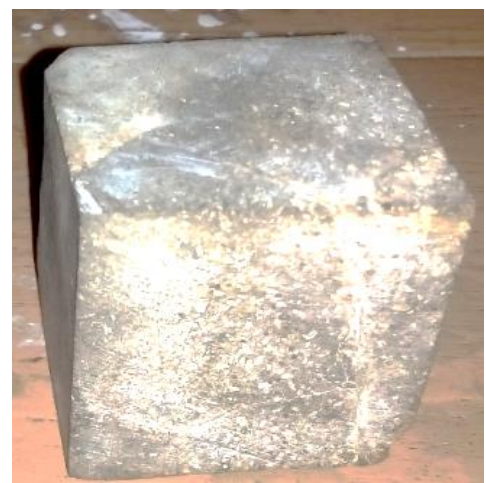

(a)

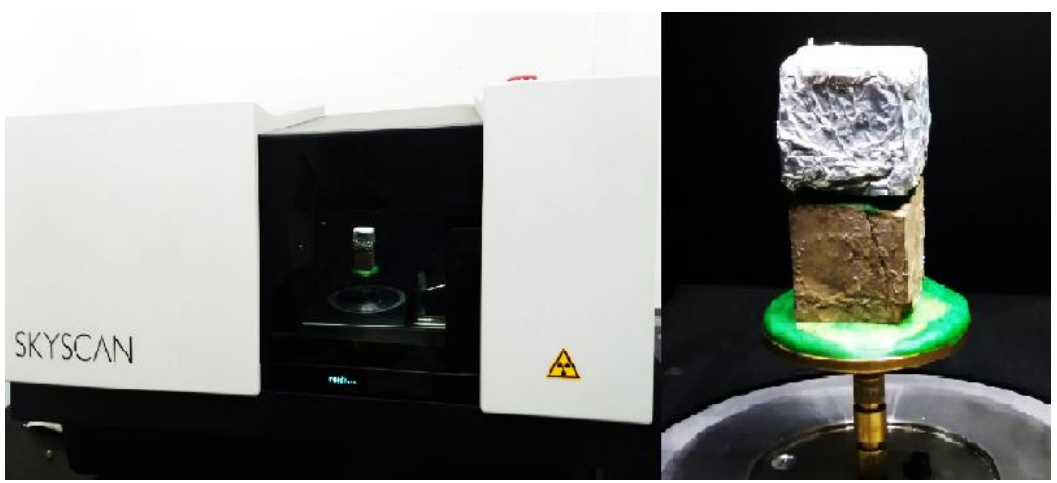

(b)

GAMBAR 1. (a) Sampel batuan reservoir geothermal. (b) Proses pemindaian sampel menggunakan micro-CT Scanner Bruker Skyscan 1173.

Selanjutnya untuk pengolahan analisis kualitatif citra 3D penulis menggunakan perangkat lunak CTVox. Dari hasil pengolahan citra untuk analisis kualitatif 3D diperoleh sebuah citra greyscale 3D volumetrik di mana skala abu bergantung pada tingkat atenuasi pada sampel batuan (dapat dilihat pada GAMBAR 2 e).

Analisis kualitatif pada citra sampel 3D akan dianalisis distribusi densitas tinggi dan densitas rendah pada sampel batuan di mana pada densitas rendah dapat diidentifikasi apakah densitas rendah tersebut termasuk ke dalam jenis pori ataukah rekahan. Analisis kuantitatif dilakukan dengan perhitungan ukuran pori, porositas terbuka, porositas tertutup, porositas total serta dimensi fraktal menggunakan perangkat lunak CTAn.

Porositas dihitung dengan menggunakan Persamaan berikut

$$
\Phi=\frac{\text { Volume Pori }}{\text { Volume Total Sampel }}=\frac{V_{p}}{V_{T}}
$$

dengan $V_{p}$ adalah volume pori dan $V_{r}$ adalah volume keseluruhan sampel. Persamaan (1) dapat digunakan untuk menghitung porositas total (termasuk tipe pori granular dan tipe pori rekahan).

Pengukuran objek fraktal 3D berdasarkan pada pengertian dimensi fraktal HausdorffBesicovitch adalah

$$
V=N(r) r^{D_{b 3 D}}
$$

dengan $r$ merupakan panjang sisi kubus, $N(r)$ adalah jumlah subkubus yang menutupi suatu objek fraktal dan $D_{b 3}$ merupakan dimensi fraktal. Dimensi fraktal sendiri merupakan dimensi dari objek fraktal yang memiliki nilai dimensi yang tidak bulat. Berdasarkan pada Persamaan (1) maka dimensi fraktal dapat diketahui. 


$$
D_{b 3}=-\frac{\Delta \ln N(r)}{\Delta \ln r}
$$

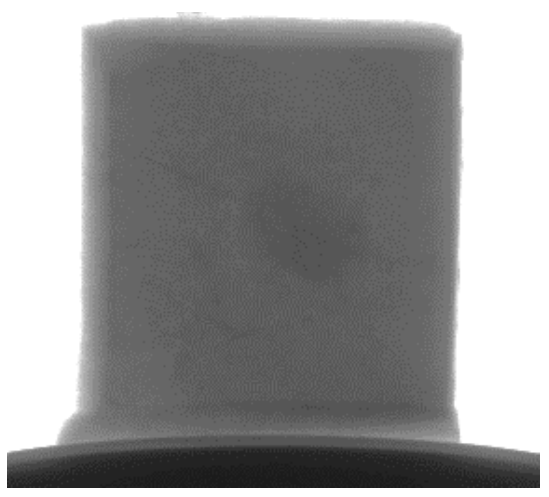

(a)

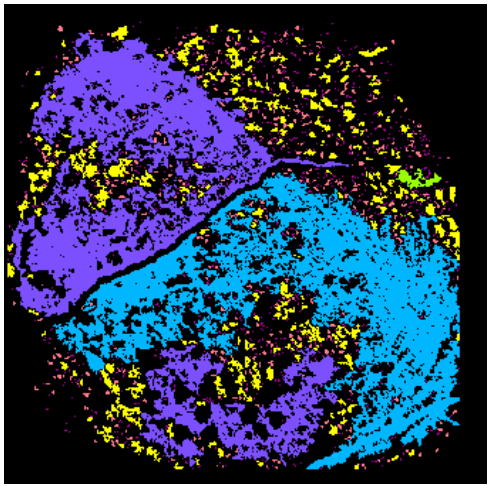

(d)

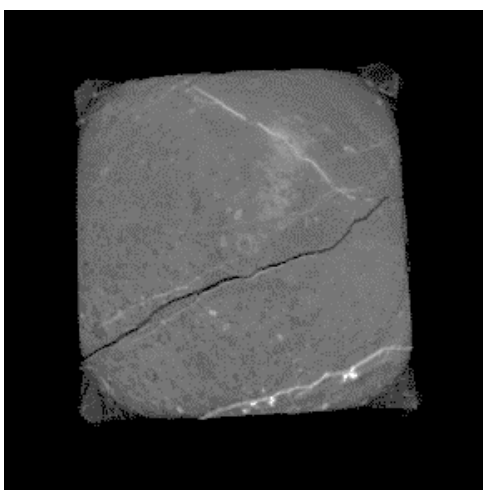

(b)

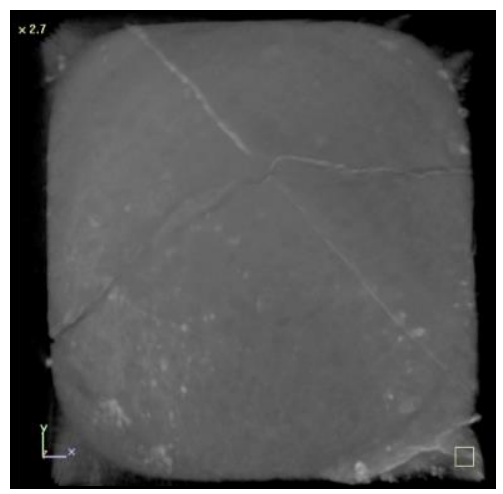

(c)

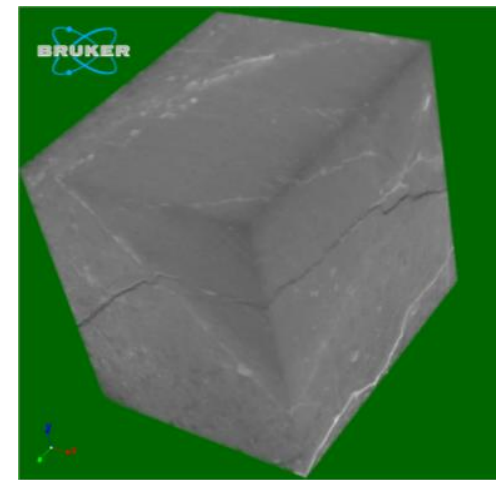

(e)

GAMBAR 2. Hasil dari prosedur-prosedur pengolahan citra.

Analisis konsensus penggunaan sumbu kartesian dari data digital dalam perangkat lunak yang digunakan (CTAn, CTVox, DataViewer, ImageJ dan Matlab). Analisis konsensus dilakukan dengan menelaah citra 2D irisan trans-axial (bidang $X Y$ ), sagittal (bidang $Z Y$ ), dan coronal (bidang $X Z$ ).

\section{HASIL DAN PEMBAHASAN}

Setelah dilakukan serangkaian prosedur pengolahan citra sampel, maka diperoleh hasil yang dapat dianalisis sebagai berikut. Dari citra irisan dan grafik batang yang terdapat pada GAMBAR 3 a, maka diperoleh bahwa distribusi ukuran objek yang beranekaragam. Pada citra yang ditunjukkan pada GAMBAR 3 a objek berukuran besar direpresentasikan oleh distribusi warna biru dan warna ungu kebiruan dan objek berukuran kecil direpresentasikan oleh distribusi warna merah muda dan ungu kemerahan. Adapun dari citra yang ditunjukkan pada GAMBAR 3 a dapat diamati bahwa distribusi ukuran objek yang terjadi tidak merata, di mana terdapat banyak objek yang berukuran kecil berkumpul di bagian sudut kanan atas citra Trans-Axial pada GAMBAR 3 a. Sedangkan di bagian kiri dan bawah citra hanya terdapat sedikit objek yang berukuran kecil.

Selain itu, diameter mayor dapat pula dihitung berdasarkan definisi jarak antara dua titik piksel yang paling jauh dari objek pada citra yang ditunjukkan pada GAMBAR 3 b. Diperoleh bahwa distribusi diameter mayor yang terjadi tidak merata, di mana terdapat banyak objek yang memiliki diameter mayor kecil berkumpul di bagian sudut kanan atas citra Trans-Axial pada GAMBAR 3 b. Sedangkan di bagian kiri dan bawah citra hanya terdapat sedikit objek yang memiliki diameter mayor kecil. 
Pada citra yang ditunjukkan pada GAMBAR 4, diperoleh bahwa distribusi densitas tinggi terjadi sejajar dengan bidang $x y$ dan $z y$, terdapat pula daerah dengan densitas yang cukup tinggi di tengahtengah sample batuan. Densitas tinggi tersebut menunjukan material lain yang tercampur dengan mayoritas material penyusun batuan, pada saat batuan beku terbentuk.
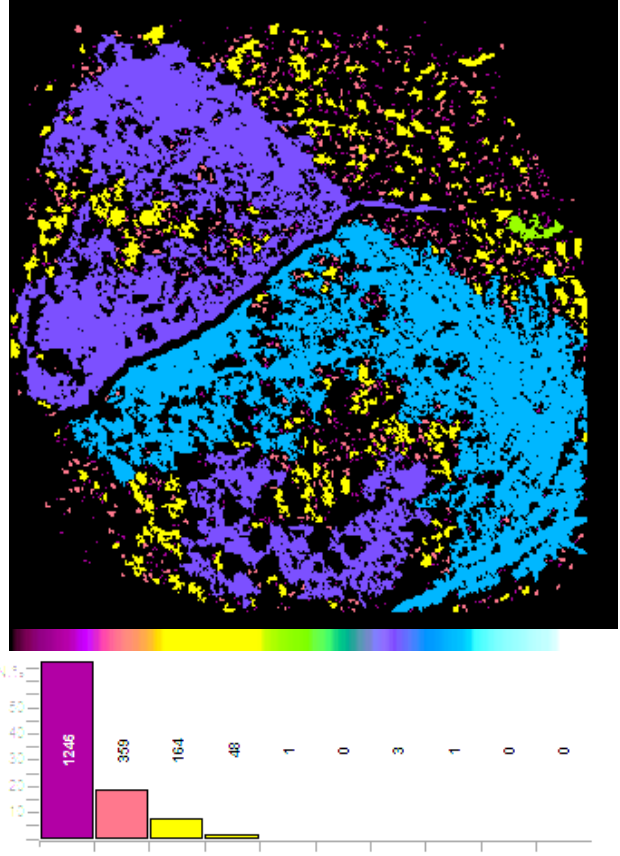

(a)
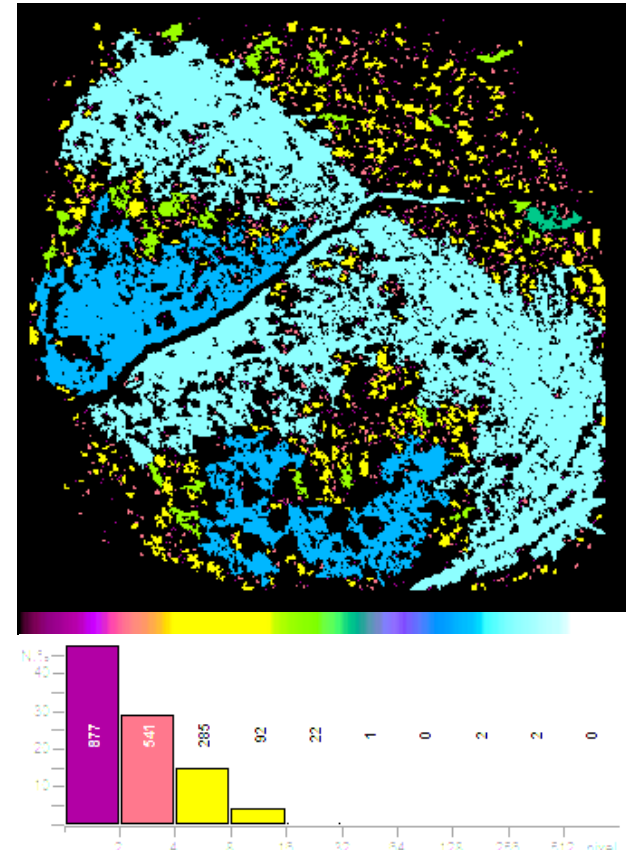

(b)

GAMBAR 3. (a) Hasil distribusi ukuran objek pada citra digital sampel batuan 2D. (b) Hasil distribusi diameter mayor objek pada citra digital sampel batuan 2D.

Pada citra yang ditunjukkan pada GAMBAR 5, diperoleh bahwa distribusi densitas rendah terjadi sejajar dengan bidang $x z$. Densitas rendah tersebut menunjukan distribusi pori maupun rekahan yang saling terkoneksi baik terbentuk pada saat sampel batuan membeku maupun setelah membeku. Pada batuan beku setelah batuan mengalami proses pembekuan terdapat aktivitas batuan yang dapat memicu terbentuknya pori maupun rekahan.
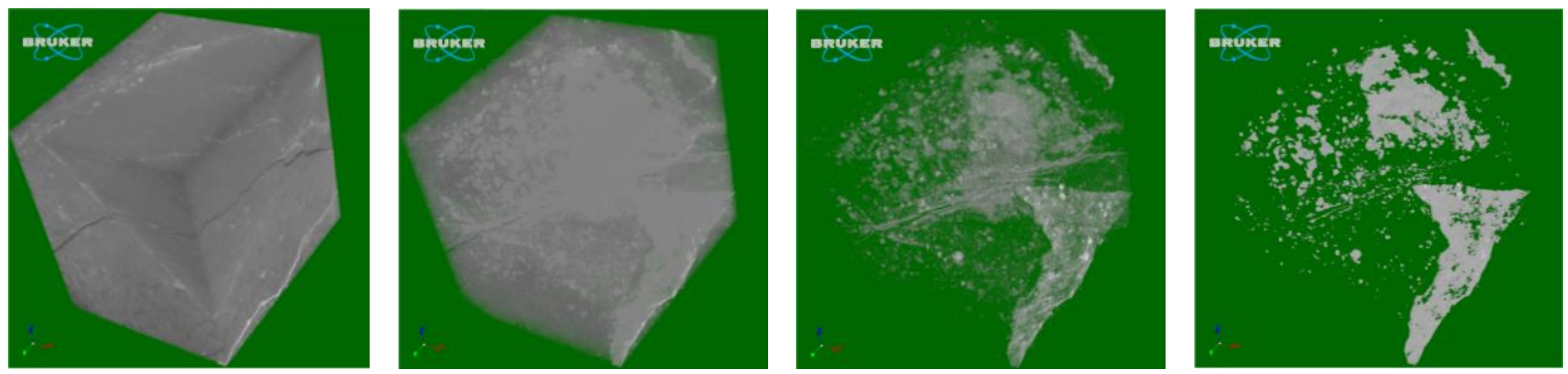

GAMBAR 4. Hasil identifikasi distribusi densitas tinggi pada citra digital sampel batuan 3D. 

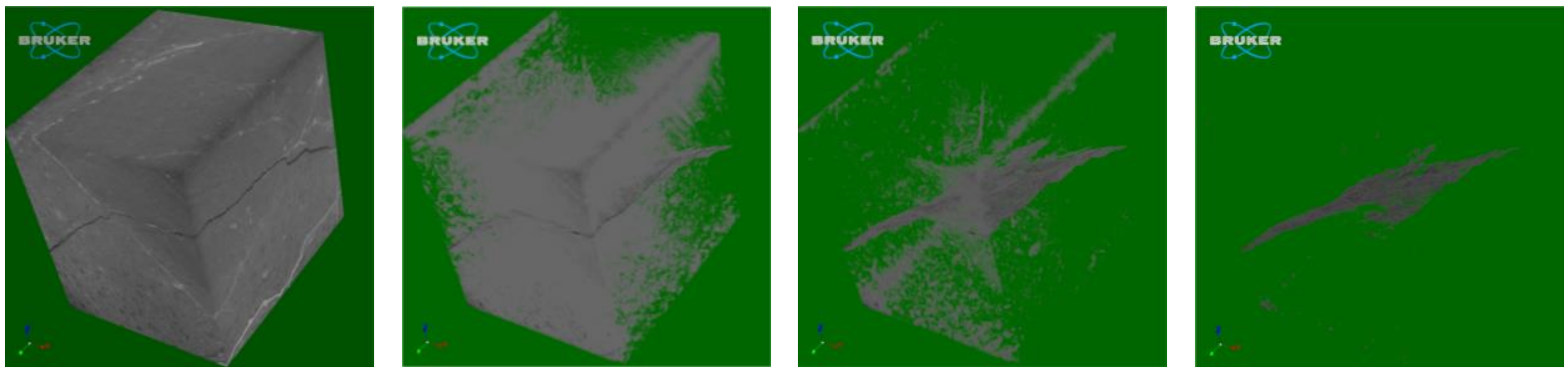

GAMBAR 5. Hasil identifikasi distribusi densitas rendah pada citra digital sampel batuan 3D.

Setelah dilakukan pengolahan data untuk analisis kuantitatif citra 3D, di mana citra hasil pengolahan data menggunakan CTAn ditampilkan pada GAMBAR 6. Maka diperoleh hasil yang ditunjukan pada TABEL 1 yang dapat dianalisis sebagai berikut. Dengan nilai ketebalan struktur rata-rata 0,649 $\mathrm{mm}$ menunjukan batuan termasuk ke dalam golongan fanerik / fanerokristalin halus. $43,884 \%$ besar porositas total dan $43,628 \%$ besar porositas terbuka pada batuan menunjukan bahwa batuan memiliki porositas yang tergolong istimewa karena besar porositas lebih dari $25 \%$. Jika $43,628 \%$ besar porositas terbuka dibandingkan dengan $0,456 \%$ besar porositas tertutup pada batuan maka dapat diidentifikasi bahwa pori-pori pada batuan terkoneksi dengan baik. Batuan memiliki nilai dimensi fraktal sebesar 2,705, hal tersebut menunjukan bahwa aliran fluida pada batuan cukup kompleks.

TABEL 1. TABEL parameter-parameter fisis batuan hasil analisis 3D CTAn.

\begin{tabular}{lc}
\hline \multicolumn{1}{c}{ Parameter } & Nilai \\
\hline Ketebalan Struktur Rata-rata (mm) & $0,649 \mathrm{~mm}$ \\
Ukuran Pori Rata-rata (mm) & $0,772 \mathrm{~mm}$ \\
Porositas Terbuka (\%) & $43,628 \%$ \\
Porositas Tertutup (\%) & $0,455 \%$ \\
Porositas Total (\%) & $43,884 \%$ \\
Dimensi Fraktal & $2,705 \%$ \\
\hline
\end{tabular}

Setelah dilakukan pengolahan analisis kualitatif citra 2D dan analisis kuantitatif citra 3D menggunakan perangkat lunak CTAn serta pengolahan analisis kualitatif citra 3D menggunakan perangkat lunak CTVox, penulis merasa perlu untuk membandingkan hasil citra dari kedua perangkat lunak tersebut beserta perangkat lunak pengolahan citra lainnya. Penulis membandingkan Citra Trans-Axial (bidang $x y$ ), Sagittal (bidang $z y$ ), dan Coronal (bidang $x z$ ) pada beberapa perangkat lunak pengolahan citra diantaranya CTAn, CTVox, DataViewer, ImageJ dan Matlab. Hasil perbandingan posisi sampel batuan yang diperoleh dari berbagai perangkat lunak menunjukkan kesamaan citra irisan pada perangkat lunak CTAn, CTVox, dan DataViewer, namun berbeda dengan hasil citra irisan pada ImageJ dan Matlab sehingga perlu perubahan sumbu kordinat jika dalam pemrosesan lanjut menggunakan kedua perangkat tersebut (dapat dilihat pada TABEL 2).

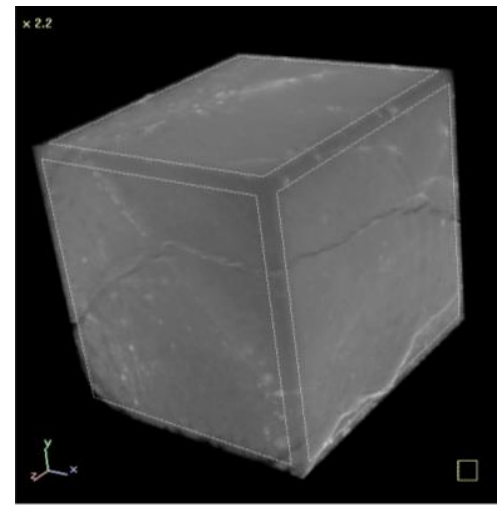


GAMBAR 6. Hasil citra digital sampel batuan menggunakan perangkat lunak CTAn.

TABEL 2. TABEL perbandingan posisi sampel batuan yang diperoleh dari berbagai perangkat lunak.

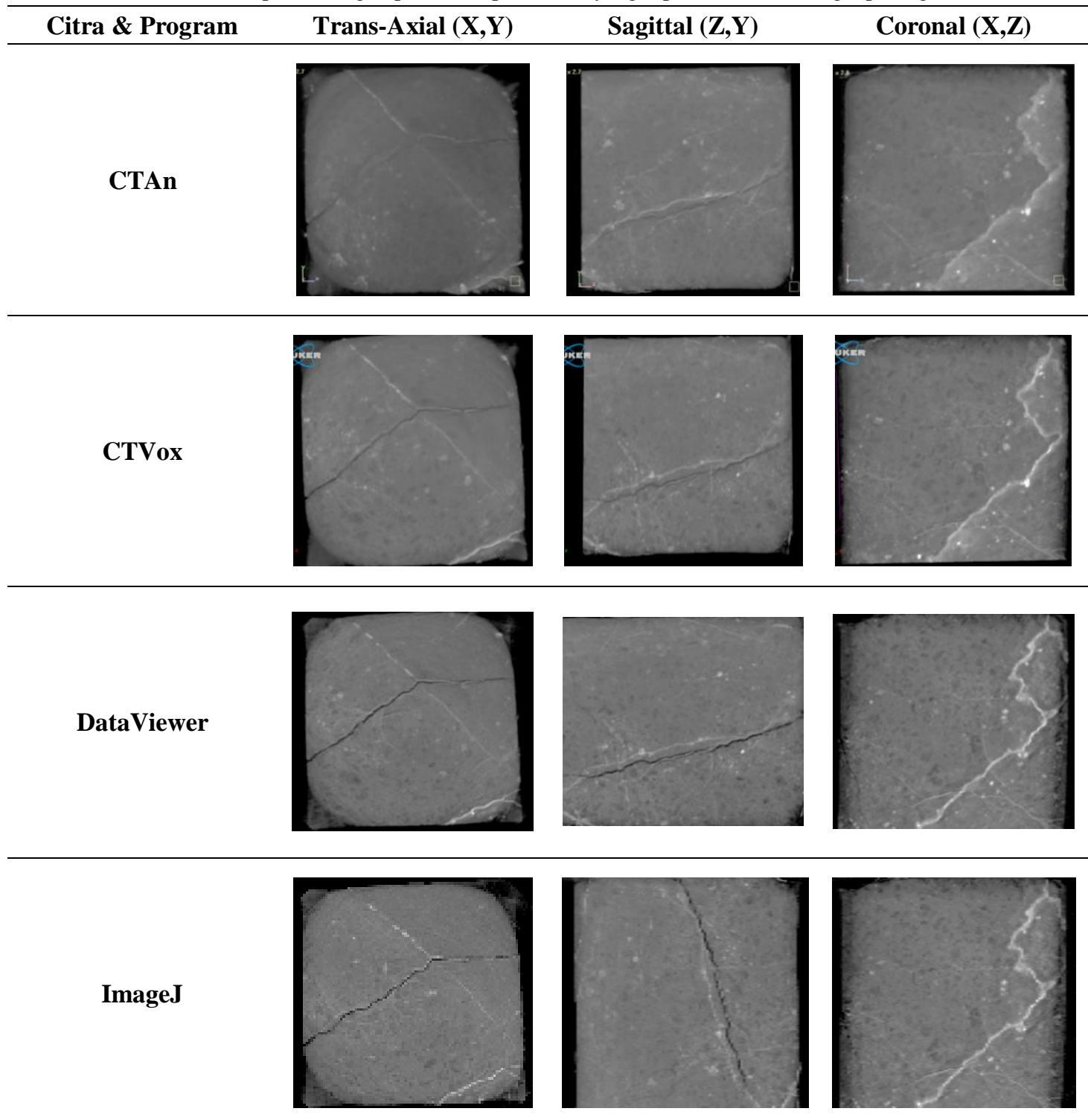




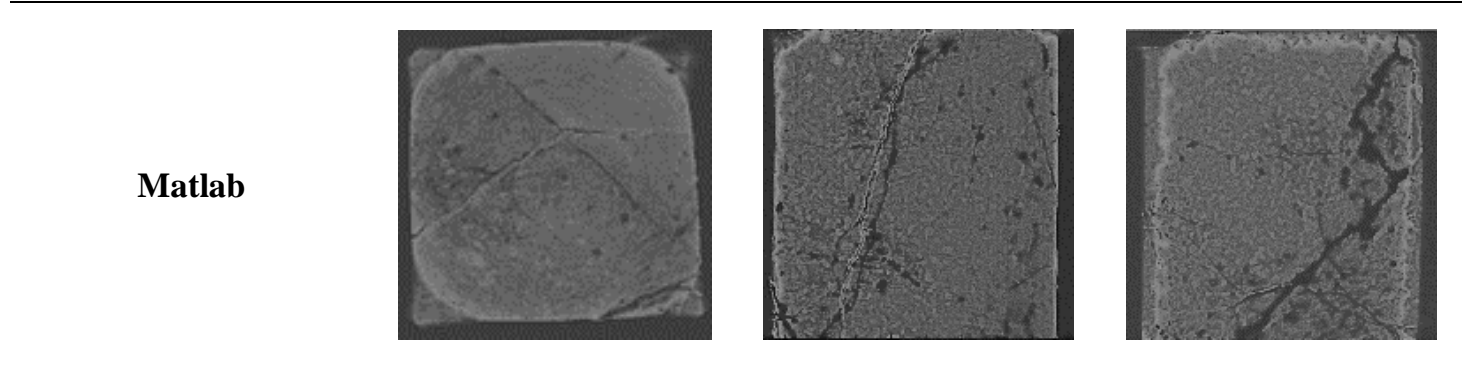

\section{PENUTUP}

Hasil parameter-parameter batuan menunjukan batuan termasuk ke dalam golongan fanerik /fanerokristalin halus, memiliki porositas yang tergolong istimewa, pori-pori pada batuan terkoneksi dengan baik, serta aliran fluida pada batuan cukup kompleks. Hasil perbandingan posisi sampel batuan yang diperoleh dari berbagai perangkat lunak menunjukkan kesamaan citra irisan pada perangkat lunak CTAn, CTVox, dan DataViewer, namun berbeda dengan hasil citra irisan pada ImageJ serta Matlab sehingga perlu perubahan sumbu kordinat jika dalam pemrosesan lanjut menggunakan kedua perangkat tersebut.

\section{UCAPAN TERIMAKASIH}

Penulis mengucapkan terima kasih kepada Firmansyah, S.Si yang telah memberikan masukan dalam penyelesaian dan penyempurnaan hasil paper ini serta kepada laboratorium instrumentasi Institut Teknologi Bandung yang telah membantu dalam proses pemindaian sampel batuan yang digunakan pada penelitian ini.

\section{REFERENSI}

[1] G. N. Sutapa, C. Anam, Uji Kecepatan Rekonstruksi Citra Pada CT-Scan Metode BackProjection (BP) dan Metode Fitered Back-Projection (FBP) Dengan Pemfilteran Pada Dominan Spasial, Jurnal Berkala Fisika, ISSN: 1410-9662, Vol. 14, No. 2, 2011, pp 33-40

[2] R. J. Barnaby, Quantitative Image Analysis for Geologic Core Description, Journal of Sedimentary, 2017, v. 87, 460-485.

[3] S. Karimpouli, P. Tahmasebi, Conditional Reconstruction: An alternative strategy in digital rock physics, Geophysics, vol. 81, no. 4 (July-August 2016); P. D465-D477.

[4] F. D. E. Latief, U. Fauzi, S. Feranie, Digital isolation technique for reconstruction and visualization of cracks in micro-CT images of geothermal reservoir rock, Microscopy and Analysis, 2012.

[5] A. Furmann, M. Mastalerz, D. Bish, A. Schimmelmann, P. K Pedersen, Porosity and pore size distribution in mudrocks from the Belle Fourche and Second White Specks Formations in Alberta, Canada, AAPG Bulletin, v. 100, no. 8 (August 2016), pp. 1265-1288. 